\title{
A Mobile Healthcare Hospital Service Platform for Personal Health Information Management
}

\author{
Long Ri Wen ${ }^{1}$, Seung Min Yang ${ }^{2}$, and Byung Mun Lee ${ }^{3 *}$ \\ ${ }^{1,2}$ Deptartment of Computer Science and Engineering, Soongsil University, Korea, \\ ${ }_{1}^{3}$ Deptartment of Computer Science, Gachon University, Korea \\ ${ }^{1}$ cmlrwen@ssu.ac.kr, ${ }^{2}$ smyang@ssu.ac.kr, ${ }^{3}$ bmlee@gachon.ac.kr
}

\begin{abstract}
One of the foremost issues in material, spiritual and cultural development is selfmanagement of personal health. The concept of personal health management includes the maintenance and promotion of human health, regular living, physical fitness and improvement, and disease prevention. In this paper, a mobile health care hospital service platform for optimal personal health management is proposed. It not only improves upon the problem of a complex visiting route, but also reduces waiting time for health care through a mobile application provided by the hospital service platform. In such cases, the hospital service platform provides convenient personal health care services and appropriate management of personal health.
\end{abstract}

Keywords: Ubiquitous health, HIS, NFC, OCS, EMR

\section{Introduction}

The registration and inspection processes in the medical industry must be designed from the perspective of a patient, not hospital staff, because it is easy to make mistakes and waste time during a patient's first visit to the hospital. Therefore, hospitals should establish policies to simplify the booking, storage, treatment, and inspection processes. However, most Korean hospitals are only interested in medical facility expansion in various forms in order to improve profitability, ignoring complicated routes and excessive waiting times. These were major complaints of hospital service users [1], and the bottleneck phenomenon at the patient reception window has a very negative impact on patient satisfaction and hospital productivity, becoming a major factor in hospital management.

In this paper, we propose a mobile health care hospital service platform for the commercialization of technology and dissemination to the medical technology industry which also provides a personal health monitoring and management solution. Furthermore, the effectiveness of the proposed platform is proven through an experiment and service evaluation.

Chapter 2 presents related research on health care technology status and trends, principally regarding changing the health care service paradigm and health care system development trends. The IT environment for the hospital service platform is also included. Chapter 3 describes the proposed hospital health care service model, subscribed system configuration, and the main services and features of the system. System development and experiment results are analyzed in chapter 4, and the conclusion is presented in chapter 5 .

* Corresponding Author 


\section{Related Research}

Previous research studied health care information-based mobile services for patients using the theory of constraints (ToC) methodology as well as the development of reception systems [1]. The mobile medical reservation system was studied using a geographic information service [2], and a mobile health care system for personal emergency management [3] to reduce patient waiting time was also studied. We developed a service platform for health management to be used in hospitals and applied the analyzed EMR system characteristics to the platform as well as integrating the medical information system and $u$-Health service environment [5] to maximize usefulness and convenience [4]. Implementation of the proposed platform was preceded by previous surveys of hospital service models [6], medical-IT fusion technology trends, and forecast depth research.

\subsection{Mobile Health Care Service Model}

Changing of the health care services paradigm. An IT-based smart health care system development based on rapid changes in global health care paradigms (new paradigms of medical service) appears in Table 1.

Table 1. Changing Medical Service Environments

\begin{tabular}{|c|c|c|}
\hline $\begin{array}{l}\text { Main } \\
\text { Division }\end{array}$ & $\begin{array}{l}\text { Detailed } \\
\text { Division }\end{array}$ & Changing factors \\
\hline \multirow{8}{*}{$\begin{array}{l}\text { Change } \\
\text { drivers }\end{array}$} & \multirow{3}{*}{$\begin{array}{l}\text { Population and } \\
\text { diseases } \\
\text { changing } \\
\end{array}$} & - Aging generation growing \\
\hline & & - Growth of industry for aging generation \\
\hline & & - Increasing proportion of chronic diseases \\
\hline & \multirow{5}{*}{$\begin{array}{l}\text { Advanced } \\
\text { medical } \\
\text { technology }\end{array}$} & - Growth of U-health industry \\
\hline & & - Application of minimal invasive surgery \\
\hline & & - Activated robot surgery \\
\hline & & $\begin{array}{l}\text { - The development and application of } \\
\text { nanotechnology }\end{array}$ \\
\hline & & $\begin{array}{l}\text { - The development of personalized health } \\
\text { care technology }\end{array}$ \\
\hline \multirow{4}{*}{$\begin{array}{l}\text { Medical } \\
\text { competition }\end{array}$} & \multirow{3}{*}{$\begin{array}{l}\text { Health care } \\
\text { globalization }\end{array}$} & - Increased international moves by patients \\
\hline & & $\begin{array}{l}\text { - Overseas expansion of medical institutions } \\
\text { and hospital group coordination }\end{array}$ \\
\hline & & $\begin{array}{l}\text { - Larger hospital groups and specialization } \\
\text { and networking acceleration }\end{array}$ \\
\hline & $\begin{array}{l}\text { Specialized } \\
\text { hospitals }\end{array}$ & $\begin{array}{l}\text { - The growth of certain diseases and } \\
\text { hospitals specializing in leading } \\
\text { technology }\end{array}$ \\
\hline \multirow{3}{*}{$\begin{array}{c}\text { Policy and } \\
\text { industrial } \\
\text { infrastructure }\end{array}$} & $\begin{array}{c}\text { Policy } \\
\text { infrastructure }\end{array}$ & $\begin{array}{l}\text { - Political push for new growth in the } \\
\text { medical industry }\end{array}$ \\
\hline & \multirow{2}{*}{$\begin{array}{l}\text { Industrial } \\
\text { infrastructure }\end{array}$} & $\begin{array}{l}\text { - Importance of translational research } \\
\text { highlighted }\end{array}$ \\
\hline & & - The spread of health care clusters \\
\hline
\end{tabular}

With competition among medical institutions around the world, leading health care service institutions must provide the following services to reflect users' main concerns (health care service consumerism): wellness and healthy living; easy access to medical service; information resources; harmony with traditional and alternative medical services; and patient-friendly health policies and insurance. 
Health care system development trends. The current health care paradigm is lifetime health.

Table 2. Health Care Paradigm Periods

\begin{tabular}{|c|c|c|c|}
\hline Division & $\begin{array}{c}\text { Healthcare 1.0 } \\
\text { Public Healthcare }\end{array}$ & $\begin{array}{c}\text { Healthcare } 2.0 \\
\text { Disease Healthcare }\end{array}$ & $\begin{array}{c}\text { Healthcare 3.0 } \\
\text { Wellness } \\
\text { Healthcare } \\
\end{array}$ \\
\hline Period & $18^{\text {th }}-19^{\text {th }}$ centuries & $20^{\text {th }}$ century & $\begin{array}{l}\text { Since the } 21^{\text {st }} \\
\text { century }\end{array}$ \\
\hline $\begin{array}{c}\text { Representative } \\
\text { innovation }\end{array}$ & Iron vaccination & $\begin{array}{l}\text { Penicillin } \\
\text { discovery }\end{array}$ & $\begin{array}{l}\text { The human } \\
\text { genome project }\end{array}$ \\
\hline Purpose & $\begin{array}{l}\text { Prevention of } \\
\text { infectious diseases } \\
\text { and their spread }\end{array}$ & $\begin{array}{l}\text { Health care and } \\
\text { cure of diseases }\end{array}$ & $\begin{array}{l}\text { Disease } \\
\text { management and } \\
\text { prevention-based } \\
\text { well-being }\end{array}$ \\
\hline Key indicators & Epidemic mortality & $\begin{array}{l}\text { Life expectancy, } \\
\text { mortality from } \\
\text { serious illness }\end{array}$ & $\begin{array}{l}\text { Wellness for life, } \\
\text { hospital fee saving }\end{array}$ \\
\hline Provider & Country & $\begin{array}{l}\text { Pharmaceutical } \\
\text { and medical } \\
\text { device companies, } \\
\text { hospitals }\end{array}$ & $\begin{array}{l}\text { Existing suppliers } \\
\text { and IT/electronic, } \\
\text { construction, } \\
\text { automobile } \\
\text { companies, etc. }\end{array}$ \\
\hline Consumer & Citizen & Patient & Everyone \\
\hline $\begin{array}{l}\text { Major changes in } \\
\text { health care industry }\end{array}$ & $\begin{array}{l}\text { Vaccination, water } \\
\text { and sewage } \\
\text { distribution } \\
\text { stethoscope, } x-\text { ray } \\
\text { doctor invention } \\
\text { establishes a } \\
\text { positive framework }\end{array}$ & $\begin{array}{l}\text { Pharmaceuticals, } \\
\text { medical devices, } \\
\text { hospital } \\
\text { industrialization } \\
\text { Developing new } \\
\text { drugs and } \\
\text { therapies } \\
\end{array}$ & $\begin{array}{l}\text { Early diagnosis of } \\
\text { personalized } \\
\text { genome and health } \\
\text { care } \\
\text { U-healthcare } \\
\text { provision }\end{array}$ \\
\hline $\begin{array}{l}\text { Achievement and } \\
\text { limitations }\end{array}$ & $\begin{array}{l}\text { Epidemic mortality } \\
\text { Lack of individual } \\
\text { diseases }\end{array}$ & $\begin{array}{l}\text { Overcome serious } \\
\text { illness from the } \\
\text { development of } \\
\text { new drugs and } \\
\text { therapies } \\
\text { Increased health } \\
\text { care costs } \\
\end{array}$ & \\
\hline
\end{tabular}

Healthcare 3.0 has the following features:

(1) As the aging generation grows, medical consumers in the 21 st century do not simply seek to live long and healthy lives, but also want reduced medical costs.

(2) The concept of health care as daily routine management is changing because of above cases, and personalized treatment will spread so that early diagnosis and minimally invasive surgery for diseases will become commonplace. Patient convenience and effectiveness will increase throughout the whole process from diagnosis to aftercare.

(3) The paradigm shift is triggering trends such as health care and IT convergence with day-to-day management of patient-centered health care, diagnosis and more refined treatment. 
(4) As health care for such consumers includes a variety of demands, it must converge with various technologies such as electronics, construction, automotive, tourism, etc.

(5) It is expected that health care business opportunities in the IT industry will expand, with efficient analysis process with extensive medical data such as personal genetic information and digital imaging data.

Health care IT service environment. U-Health includes a variety of bio-sensors and various forms of health information, from sensor components to intelligent platforms, case-based reasoning, PHR (personal health records), smart media and smart security technology [7]. Figure 1 [6] depicts biological information transfer, and it can leverage existing networks. There has been a lot of progress over the past ten years in terms of measuring biometric technology research and development, but analysis and reasoning techniques related to these biometrics are not yet in use. Interest in large biometric analysis technology has increased through such research and development. In this paper, we propose a mobile health care service model.

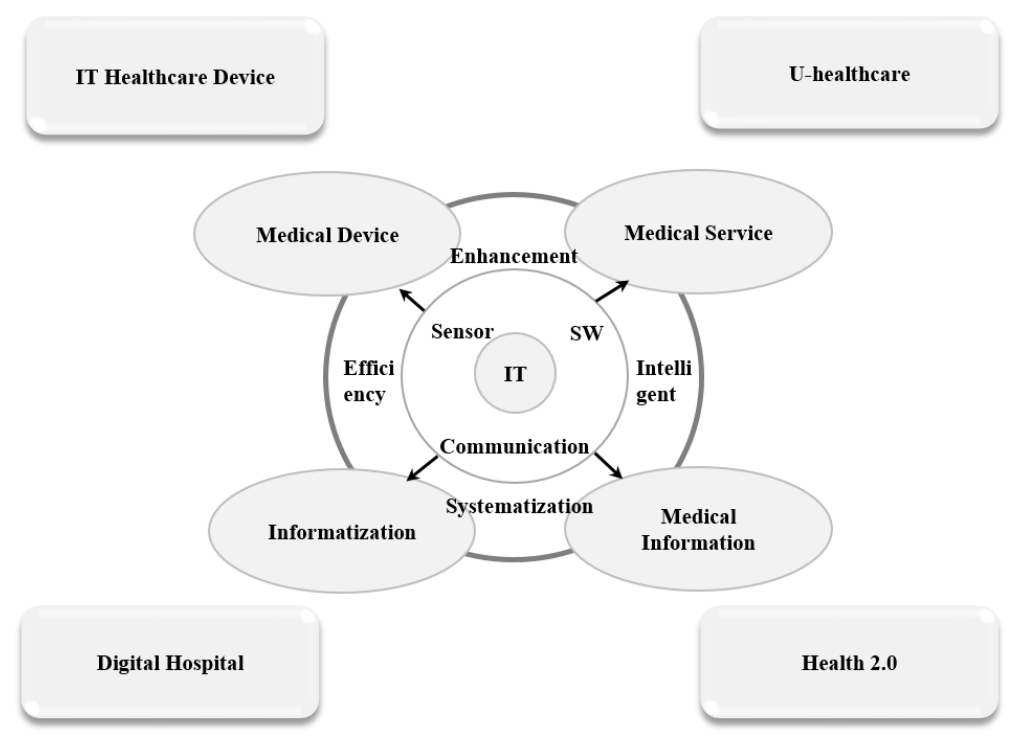

Figure 1. Fusion of Health Care and IT

Mobile health care services. The mobile healthcare application provides the services listed in Figure 2. The first feature is animation contents to confirm bookings and translation. The second feature is bookings for hospital and drugstore mobile services and electronic prescriptions. The third feature is hospital one-stop payment.

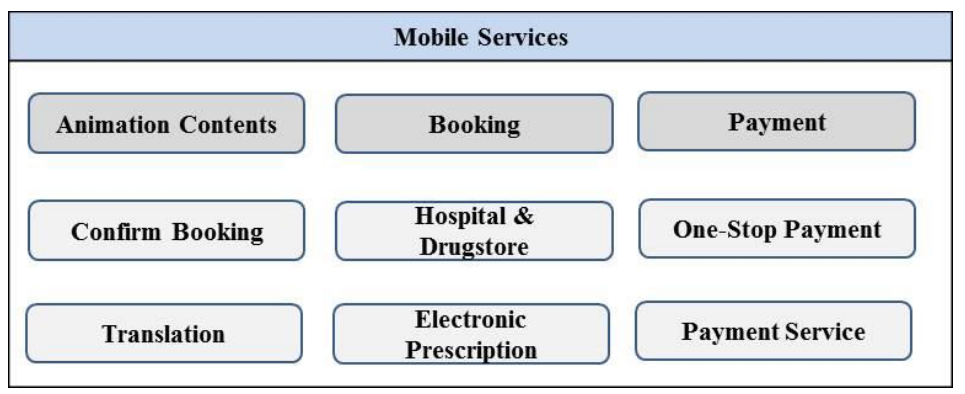

Figure 2. Mobile Health Care Application 


\subsection{Hospital Service Platform}

The major functions of the hospital healthcare service platform are shown in Figure 3 [6].

(1) Mobile appointment and notification services

Mobile health care services were scheduled to be implemented in conjunction with a medical care information system (EMR). The service also offers optional medical care professionals and a real-time reservation service. It provides visitor location-based alerts [8] to determine the health care and examination schedule for the visit as well as medical assistance and emergency response services and also offers treatment locations and related location information [9].

(2) Mobile electronic documents

OCS was linked to the implementation of patient information to provide over 200 different forms of medical records. It was implemented to explain diagnosis results saved as images to the patient with consent to electronic record-keeping evaluation. It provides on-site identification with electronic signatures for patients and agents with electronic consent.

(3) Storage and mobile payment services

EMR works in conjunction with patient information in a mobile app and can handle medical history, examination, input, output, surgery, and so on. It is possible to pay the costs of health care, including medical treatment, examination and surgery, instantly via credit card, and it provides multi-language support for foreigners.

(4) Provides health care and monitors guidance content

The system provides guidance services using animation for patients' prescriptions.

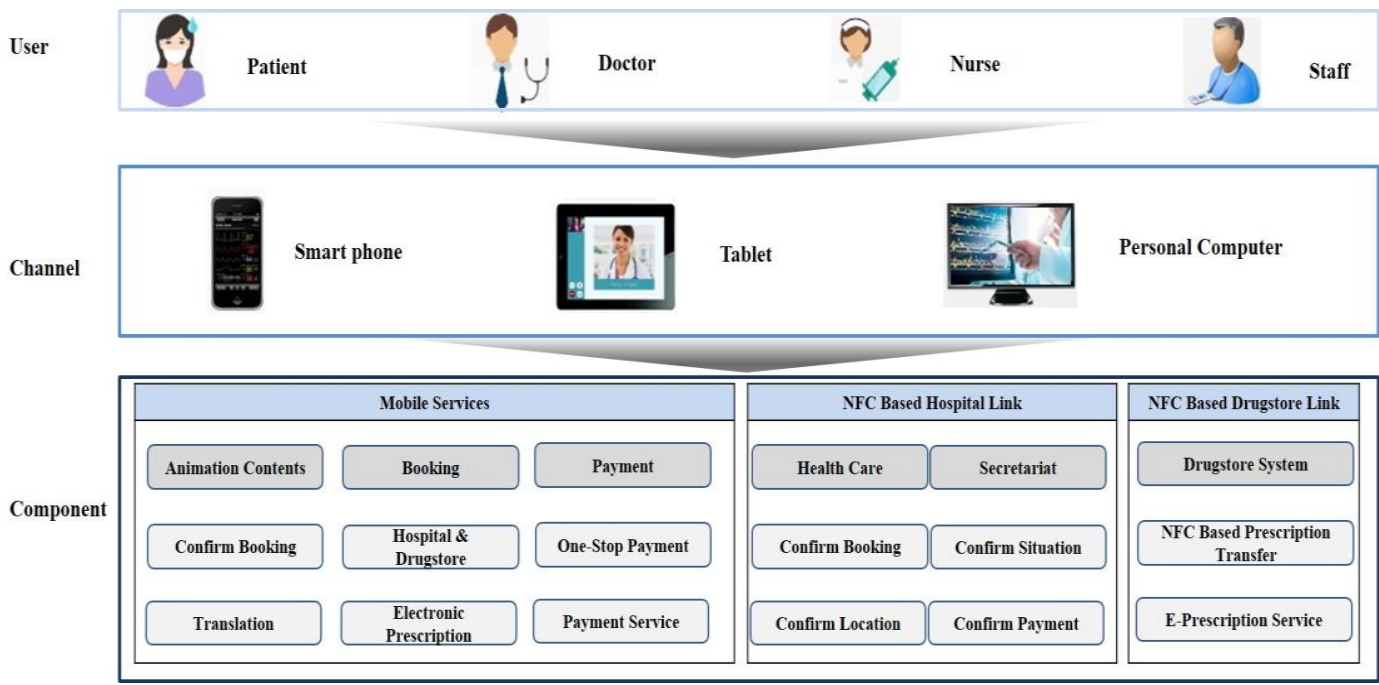

Figure 3. Hospital Health Care Service Platform Configuration

The hospital health care service platform provides user API through smart devices, tablets and PCs to request and receive platform services. 


\section{Proposed Hospital Service Platform}

\subsection{System Configuration}

The proposed hospital service platform infrastructure is shown in Figure 4.

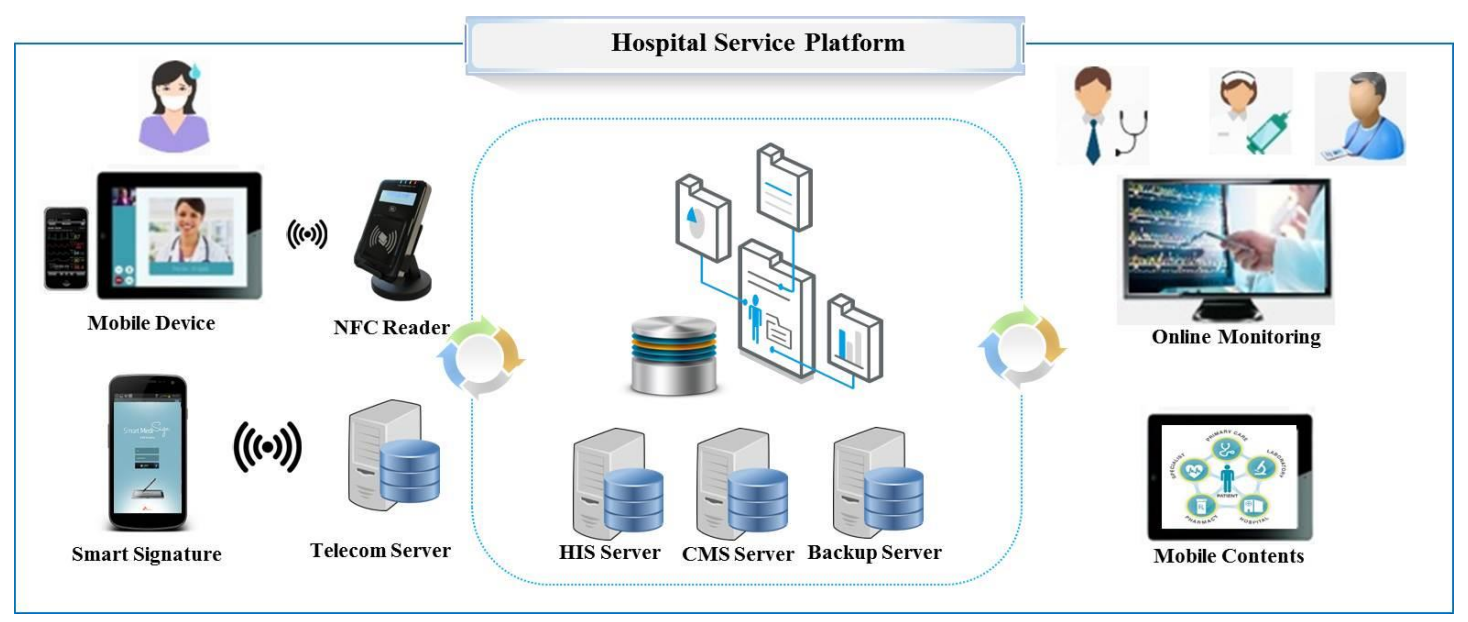

Figure 4. Hospital Service Platform Infrastructure

The hospital service platform connects users' mobiles through mobile and platform API, as shown in Figure 5.

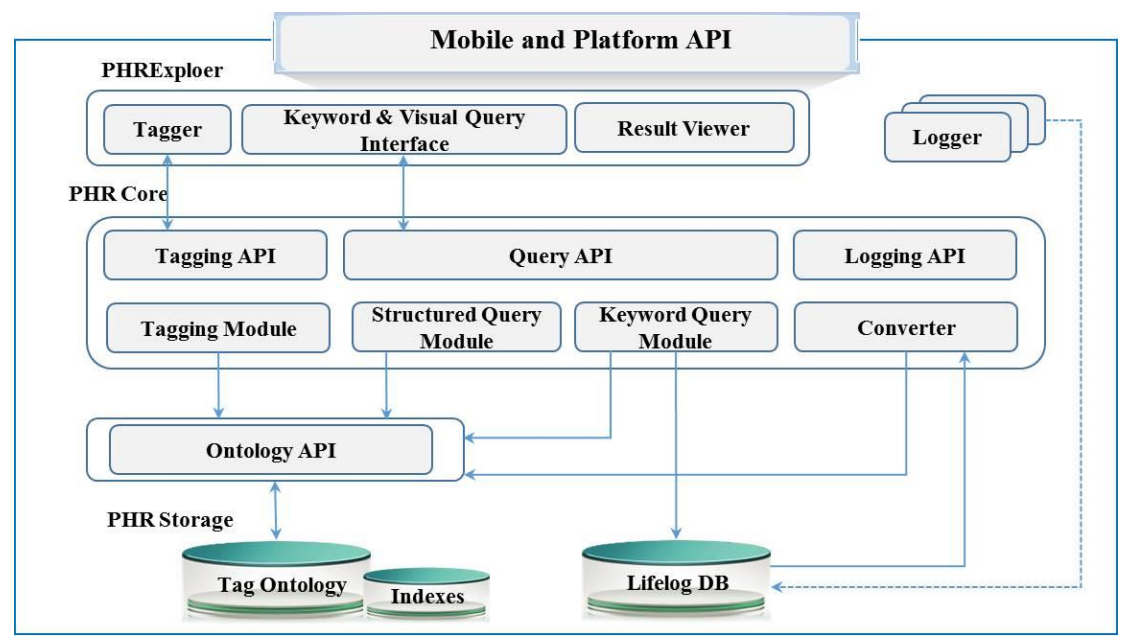

Figure 5. Service API Architecture

The main technology is NFC-based standard telecommunications, and using it to control personal authentication also provides guidance on movement routes and DID health care. The main functions are NFC tagging and NFC tag-based guidance as well as HIS (hospital information system) connection.

(1) NFC-based telecommunications

The main system uses ISO/IEC 18092-based mobile and hospital device P2P (peerto-peer) telecommunications along with communication between the NFC reader and control PC using USB and communication based on a socket protocol for the control PC and platform web server.

(2) NFC tagging process

The whole process is shown in Figure 6. When the user logs into the mobile application, the web server then applies the patient information key. When the user 
tags their mobile to the NFC reader, then the patient key and device key will transmit to the end PC connected to the NFC reader. The web server will make a decision that if there is additional data on req1002, there is a reservation, and that if there is additional data on req1002, it has been received. Reservation and reception information such as patient number, reservation date and time, and health care center will be sent to the user's mobile at the same time they are displayed on the DID. Ultimately, the logging data will be saved on the data server.



Figure 6. NFC Tagging Process

(3) NFC tag-based guidance

The NFC tag-based guidance service not only provides information about patient movement routes in the hospital, but also provides real-time reservation status and reception status through the mobile application.

(4) Mobile application HIS connection

The first step is user information processing, when the user logs in from the mobile application. The platform proceeds with user recognition to connect HIS health information with mobile user information and connects user health information that matches on HIS. The second step is health care reservation information processing, and at this step the health care center data and doctor data are connected. The third step is reception information processing, when reception, health care cost and waiting status are connected. The fourth step is NFC-based information processing, and at this step, mobile NFC and patient information are connected and information by the NFC reader is synchronized with the health care server while location information from the hospital is also synchronized with NFC information. The operation system configuration is shown in Figure 7. 


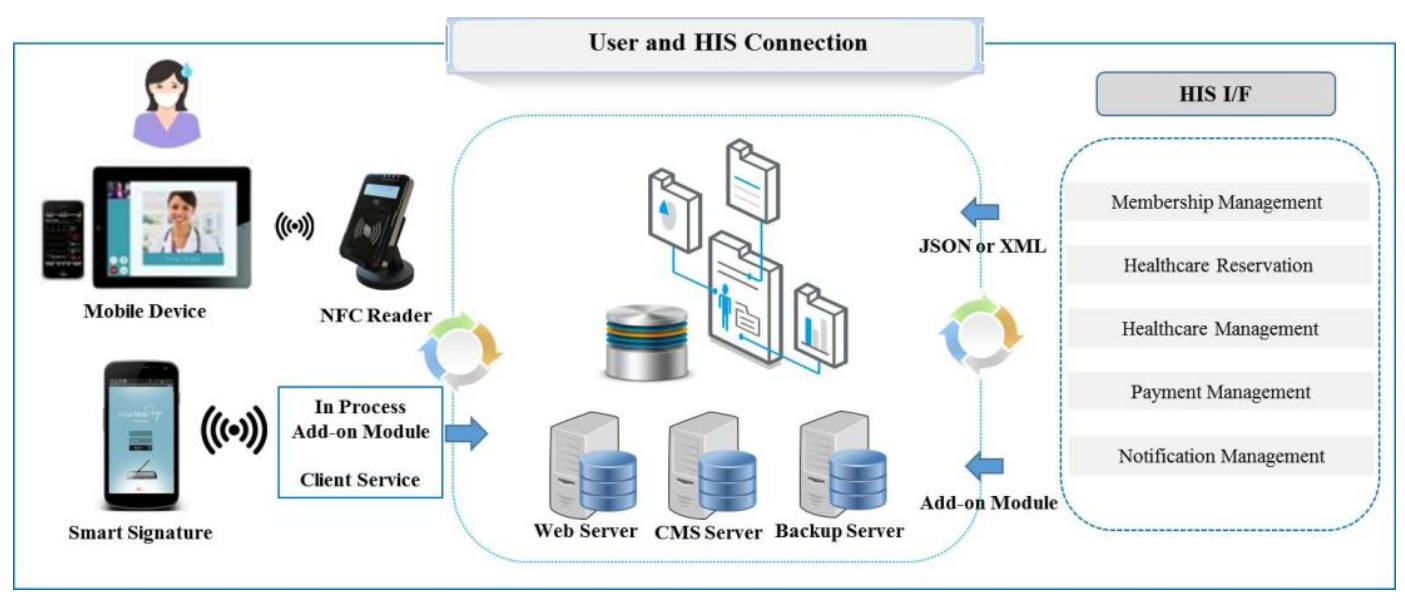

Figure 7. HIS Connection Configuration

\subsection{System Services and Features}

An outline of the hospital service configuration is shown in Figure 8.

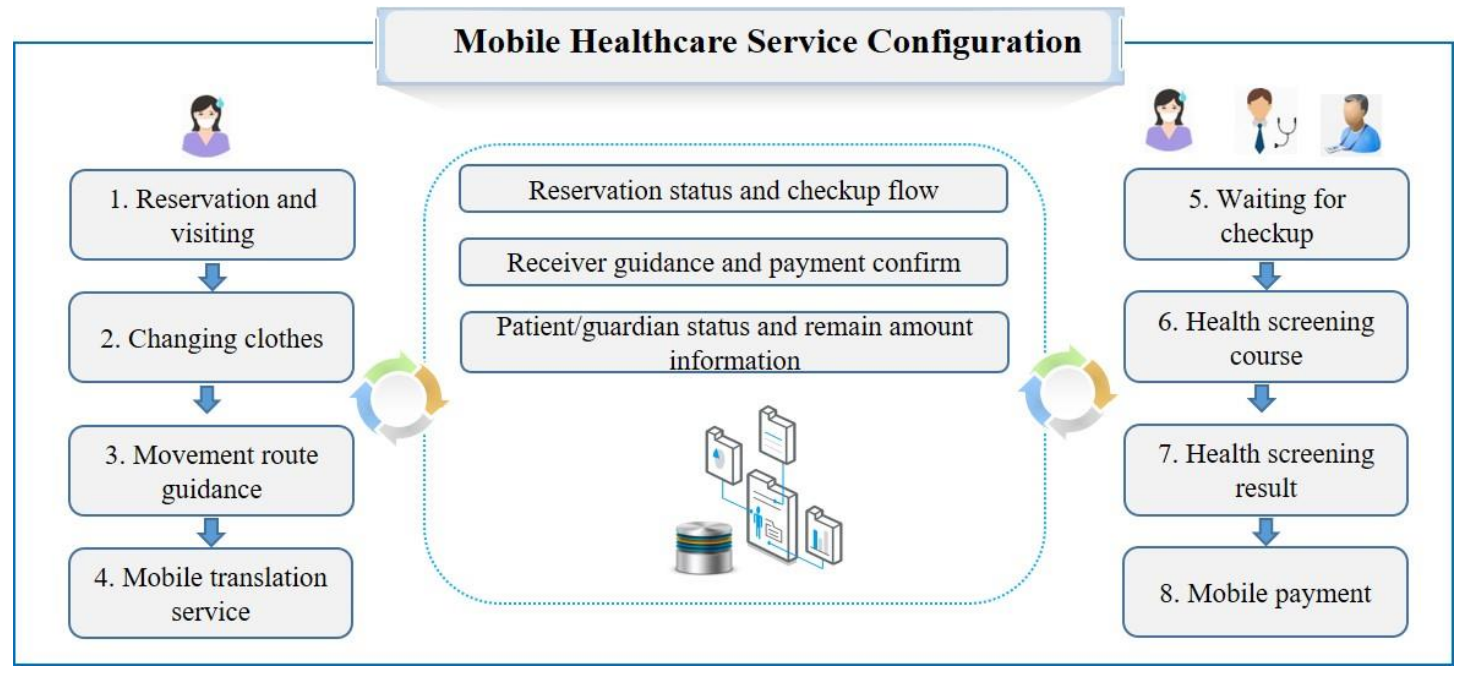

Figure 8. Hospital Service Configuration

The first step is mobile reservation and visiting. This step includes diagnosis and checkup reservation, reception, real-time notification, checkup course setting, and checkup office management. Date selection is available for diagnosis and checkup reservations using mobile reservation and doctor selection.

When a reservation is made via mobile for treatment or checkup, if a prior interview process is added, the treatment team or date are selected or a reservation notification checking service may be provided. With the notification service, a service notifying of visitors' expected arrival times is provided and checkup room changes can easily be made, while checkup room administration functions may also be supported. All these take the patient's viewpoint into consideration for more efficient checkup room administration.

The second step is for changing clothes. NFC technology is used for the service that stores individual items, including clothing, before checkups for easy opening/locking of the lockers. The third step is movement route guidance. The platform provides NFC-based movement route guidance and real-time flow management for movement route guidance in the hospital. The fourth step is mobile 
translation service. Mobile service and medical translation services are provided in three languages for foreign users.

The fifth step is waiting for checkup service. This step includes checkup office registration, checkup notification, and checkup and waiting status along with checkup device guidance services. It must be possible to check the waiting status of each checkup room to provide checkup room registration and notification services, and a service to register as a waiting checkup room patient is provided. Furthermore, there is a notification service using vibrations or the mobile phone screen when it is that patient's turn. Monitoring of checkups and patients waiting for each checkup room is provided for checkup room and waiting inquiries. The platform provides diagnosis and checkup device animation guidance and information on the checkup process.

The sixth step is health screening course service. Information about the checkup course is shared in real-time with the patients and their family. The seventh step is health screening results. A paperless mobile electronic message is sent with health care results. The eighth step is mobile payment service. This is an easy payment service that provides treatment and payment services based on electronic notifications.

\section{Evaluation}

Comparative pre-/post-application of hospital health care service platform results appear in Table 3.

Table 3. Comparative Analysis of Platform Application

\begin{tabular}{|c|l|l|}
\hline Category & \multicolumn{1}{|c|}{ Before } & \multicolumn{1}{c|}{ After } \\
\hline $\begin{array}{c}\text { Diagnosis and } \\
\text { screening } \\
\text { reservations }\end{array}$ & Booking through phone service or or & $\begin{array}{l}\text { Emergency, diagnosis, and } \\
\text { checkup reservation services } \\
\text { provided, tailored treatment } \\
\text { services provided to visitors }\end{array}$ \\
\hline $\begin{array}{c}\text { Diagnosis and } \\
\text { screening } \\
\text { guidance }\end{array}$ & $\begin{array}{l}\text { Staff guidance; } \\
\text { Unknown estimated time of } \\
\text { patient visits }\end{array}$ & $\begin{array}{l}\text { Mobile service based guidance; } \\
\text { location based mobile } \\
\text { guidance; } \\
\text { real-time mobile notification of } \\
\text { patient arrival time }\end{array}$ \\
\hline $\begin{array}{c}\text { Diagnosis reception } \\
\text { method }\end{array}$ & $\begin{array}{l}\text { Visiting and waiting for cashier; } \\
\text { The appropriate office waits } \\
\text { after receiving }\end{array}$ & $\begin{array}{l}\text { Immediately accepted via } \\
\text { mobile application; } \\
\text { Confirm and modify the } \\
\text { reception using the mobile } \\
\text { service }\end{array}$ \\
\hline $\begin{array}{c}\text { Registration and } \\
\text { queue waiting time }\end{array}$ & $\begin{array}{l}\text { Waiting at registration office; } \\
\text { Confirm order at guidance } \\
\text { monitor }\end{array}$ & $\begin{array}{l}\text { Registration office using the } \\
\text { mobile service; } \\
\text { Confirm the order using the } \\
\text { mobile NFC service; } \\
\text { Confirm the expected waiting } \\
\text { time }\end{array}$ \\
\hline $\begin{array}{c}\text { Health care } \\
\text { notifications }\end{array}$ & Wait for staff call & $\begin{array}{l}\text { Real-time notification service } \\
\text { anywhere in hospital without } \\
\text { space limitations }\end{array}$ \\
\hline $\begin{array}{c}\text { Health care steps } \\
\text { guidance }\end{array}$ & Described by nurse & $\begin{array}{l}\text { All health care courses directed } \\
\text { to the mobile service }\end{array}$ \\
\hline
\end{tabular}




\begin{tabular}{|c|c|c|}
\hline Category & Before & After \\
\hline $\begin{array}{c}\text { Health care location } \\
\text { guidance }\end{array}$ & Staff guidance & $\begin{array}{l}\text { Mobile movement route } \\
\text { guidance }\end{array}$ \\
\hline Health care reception & Visit or call reception & $\begin{array}{l}\text { Mobile service or NFC-based } \\
\text { immediate acceptance; } \\
\text { Confirm health care steps using } \\
\text { the mobile service }\end{array}$ \\
\hline $\begin{array}{l}\text { Confirm the office } \\
\text { and order }\end{array}$ & Registered manually & $\begin{array}{l}\text { Registered using NFC reader; } \\
\text { Real-time order confirmation }\end{array}$ \\
\hline $\begin{array}{l}\text { Prior inspection } \\
\text { guidance }\end{array}$ & $\begin{array}{l}\text { Unknown preceding checkup } \\
\text { information }\end{array}$ & $\begin{array}{l}\text { Automatic notification of prior } \\
\text { checks; } \\
\text { Provision of medical device } \\
\text { information using animation }\end{array}$ \\
\hline $\begin{array}{l}\text { Equipment and } \\
\text { electronic locker }\end{array}$ & Keep tag and key for locker & $\begin{array}{l}\text { Using the mobile NFC control } \\
\text { equipment and locker }\end{array}$ \\
\hline $\begin{array}{c}\text { Inspection and health } \\
\text { care results }\end{array}$ & By mail & By inspection sent via mobile \\
\hline Payment service & $\begin{array}{l}\text { General cashier and fare } \\
\text { adjustment machine }\end{array}$ & $\begin{array}{l}\text { Mobile postpaid billing } \\
\text { services }\end{array}$ \\
\hline Aftercare & $\begin{array}{l}\text { After individual interviews or } \\
\text { visits }\end{array}$ & $\begin{array}{l}\text { Teleconference calls using } \\
\text { mobile service }\end{array}$ \\
\hline $\begin{array}{l}\text { Services for } \\
\text { foreigners }\end{array}$ & Coordinating interpreters & $\begin{array}{l}\text { Mobile foreigner health care } \\
\text { service; } \\
\text { Mobile medical terminology } \\
\text { translation service }\end{array}$ \\
\hline
\end{tabular}

As shown in Table 4, it normally takes 74.3 minutes of waiting time to receive treatment and 7.2 minutes to be treated in Korea. Application of the hospital health care platform and mobile service should reduce patient time at the hospital to half an hour as well as cutting down on hospital costs.

Table 4. General Time Spent in Hospital for Health Care

\begin{tabular}{|c|c|c|}
\hline \multirow{2}{*}{ Step } & \multicolumn{2}{|c|}{ Time Spent } \\
\cline { 2 - 2 } & Current & Predicted \\
\hline Intake & 9.2 minutes & \multirow{2}{*}{15 minutes } \\
\hline Waiting for treatment & 22.7 minutes & \multirow{2}{*}{7.2 minutes } \\
\hline Waiting for checkup & 14.2 minutes & \multirow{2}{*}{15 minutes } \\
\hline Treatment & 7.2 minutes & \\
\hline Medication dispensing & 15.3 minutes & \\
\hline Fee payment & 5.7 minutes & $\mathbf{3 7 . 2}$ minutes \\
\hline Total & $\mathbf{7 4 . 3}$ minutes & \\
\hline
\end{tabular}




\section{Conclusion}

The mobile hospital service platform using an NFC smart sensor and the mobile application both use a personal health monitoring service to provide personal health care guidance in the hospital. The optimal screening procedure at the present time selects a service to reduce waiting time and provides information via linkage between the DID.

Health care is changing to customized health care based on changing trends in health care paradigms, and maintaining health through disease prevention and daily health management with the core goal of "the era of a healthy life" is the current paradigm. Thus, the mobile health care service based on a hospital health care service platform proposed in this paper is applicable to personalized health care services and personalized services after treatment.

\section{Acknowledgements}

This work was supported by the Catholic Kwandong University, International ST. Mary's Hospital research fund of 2014 (S1004-14-1049).

\section{References}

[1] C. S. Park. and S. H. Koh, "A Case Study on the Improvement of General Hospital Outpatients Waiting Time using TOC Methodology”, Korean Journal of Hospital Management, Korean Society of Hospital Management, vol. 16, no. 1, (2011), pp. 77-100.

[2] K. T. Rho and Y. H. Kim, "An Implementation of Mobile Medical Reservation System using Geographic Information Service", The Journal of IIBC, The Institute of Internet, Broadcasting and Communication, vol. 10, no. 2, (2010), pp. 173-178.

[3] S. M. Chun and J. Y. Park, "Mobile Health Care System for Personalized Emergency Management", Journal of the IEIE, The Institute of Electronics Engineers of Korea, vol. 51, no. 6, (2014), pp. 50-59.

[4] H. J. Im, J. T. Shim and S. S. Lee, "The Study on Impact of Introduction Characteristics Factor of EMR System on Perceived Usefulness and Ease of Use and Behavioral Intention to Use", Journal of the KSIIS, Korea Society of Industrial Information Systems, vol. 14, no. 2, (2009), pp. 32-50.

[5] Y. Y. Sok and S. H. Kim, "Integrated Medical Information System Implementation for the u-Healthcare Service Environment", Journal of the Korea Contents Society, The Korea Contents Society, vol. 14, no. 5, (2014), pp. 01-07.

[6] L. R. Wen, S. M. Yang and B. M. Lee, "Study on the Hospital Health Care Service Model", Proceedings of the international workshop mechanical engineering, Jeju, Korea, (2016).

[7] S. H. Kim, "Medical - IT Fusion Technology Trends and Forecasts", The Korean Magazine of the IEEK, The Institute of Electronics Engineers of Korea, vol. 37, no. 6, (2010), pp. 49-59.

[8] T. B. Yun, J. H. Lee and G. H. Lee, "The Development of u-Drug Cap based on NFC for Medication Information Management", The Journal of the KAIS, Korea Academia-Industrial Cooperation Society, vol. 16, no. 3, (2015), pp. 2165-2171.

[9] Y. R. Lee and S. H. O, "A Secure Mobile Payment System for Near Field Communication System”, The Journal of the KAIS, Korea Academia-Industrial Cooperation Society, vol. 14, no. 7, (2013), pp. 34873494 . 


\section{Authors}

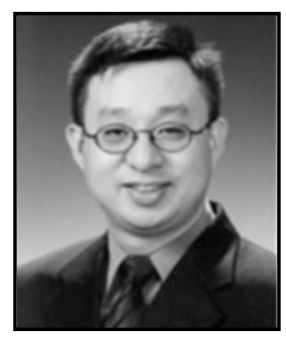

Long Ri Wen, he received a B.S. degree in 1999 from Yanbian University, Yanji, China and a M.S. degree from Soongsil University in 2012. He had worked in R\&D institute of Catholic Kwandong University, International St. Mary's Hospital for several years. He is currently Ph.D. candidate at Soongsil University and a manager in the department of Project Development, Macrogen Co., Ltd. His research interests are personal bio record based healthcare, healthcare and ICT convergence, its network protocol, IoT for healthcare, wireless sensor networks, operating system, Cloud computing, Big data analysis, etc.



Seung Min Yang, he received a B.S. degree in 1978 from Seoul University, Seoul, Korea and a M.S. degree and a Ph.D. degree from University of South Florida, USA in 1983 and 1986. $\mathrm{He}$ had worked as a professor in the department Computer Science, University of South Florida for 6 years. He is currently a professor in the department of Computer Science and Engineering, Soongsil University. His research interests are real time system software, system fault tolerance, wireless sensor networks, operating system, etc.

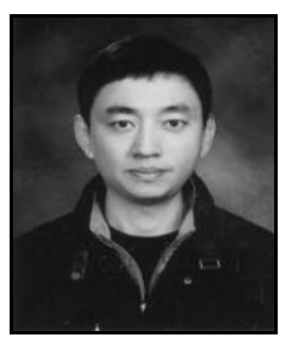

Byung Mun Lee, he received a B.S. degree in 1988 from Dongguk University, Seoul, Korea and a M.S. degree from Sogang University and a Ph.D. degree from University of Incheon Korea, in 1990 and 2007. He had worked for LG Electronics for 7 years. He is currently a professor in the department of Computer Engineering, Gachon University, South Korea. He had been at California State University Sacramento, USA from 2013 to 2014 as a visiting scholar. His research interests are pervasive healthcare, its network protocol, IoT for healthcare, wireless sensor networks, operating system, etc. 